\title{
Planning in the Poncini Family Business
}

\author{
Mary A. Barrett, Luca Gottardi, and Ken Moores \\ Wollongong University, New South Wales, Australia
}

$\mathrm{T}$

wo brothers, Carlo and Lorenzo Poncini, leaned against one wall of a large, tiled building in the Trentino countryside in northern Italy. It was late afternoon in early May 2015, but the air was still warm as the sun dipped behind the distant snow-capped mountains. The words "Poncini Autotrasporti" were painted on the wall, and a number of trucks were parked close by. However, the two men were not looking at the trucks but rather were gazing towards two vineyards that stretched down towards a deep valley in the distance. They each held a glass of one of the excellent local wines as they admired the vineyards that promised a spectacular harvest in a few months' time if the weather held. Anyone overhearing their conversation, however, would soon have been aware that the two men were not simply enjoying a quiet moment in an idyllic setting.

The older brother, Carlo, spoke first. "Well, Lorenzo, it’s good to have you back home with us. We missed you, but we were happy to know that you were studying hard and finishing your thesis.”

Lorenzo:

I had a marvelous time while I was away, but it's wonderful to be back here in Italy. I can't thank you and Angelo enough for looking after my tasks while I was in Australia. Still, coming home after so long makes some things here look strange. We seem to be involved in so many diverse businesses. Why do we have so many? We're only a small firm, after all.

Carlo:

I've never really thought about it. It just happened, I suppose. Opportunities just came along, and I guess we - or rather Papa, he's always been an entrepreneur - were happy to experiment and find a new market. It seems like lots of things worked out because, as you say, here we are with all these diverse businesses. The big question now is whether we continue the wine experiment. What do you think? You're interested in a role on the wine side of things, aren't you?

Lorenzo thought of all the years he had spent diligently studying wine economics. At last, an 
opportunity to use his expertise seemed to be offered. He immediately replied, "Yes, of course!" Moreover, the decision felt comfortable. It was, after all, the way the Poncini family had always made up their minds; they grabbed an obvious opportunity and ran with it. Carlo's description of their involvement in the wine industry as an "experiment" seemed apt. There were plenty of options to consider: sell the vineyards they already owned, expand (there was an opportunity to buy additional vineyards), keep sending their wine to the cooperative they had always used or consider alternatives to it. Already the choices were bewildering. Finally, he said, "Right now, the problem is not what to think about the wine experiment, but how to think about it. That's what I really need to know.”

\section{History of the Poncini family}

Lorenzo and Carlo were members of the third generation of the Poncini family-in-business. See the genogram in Exhibit 1.

\section{Exhibit 1}

\section{The Poncini family}

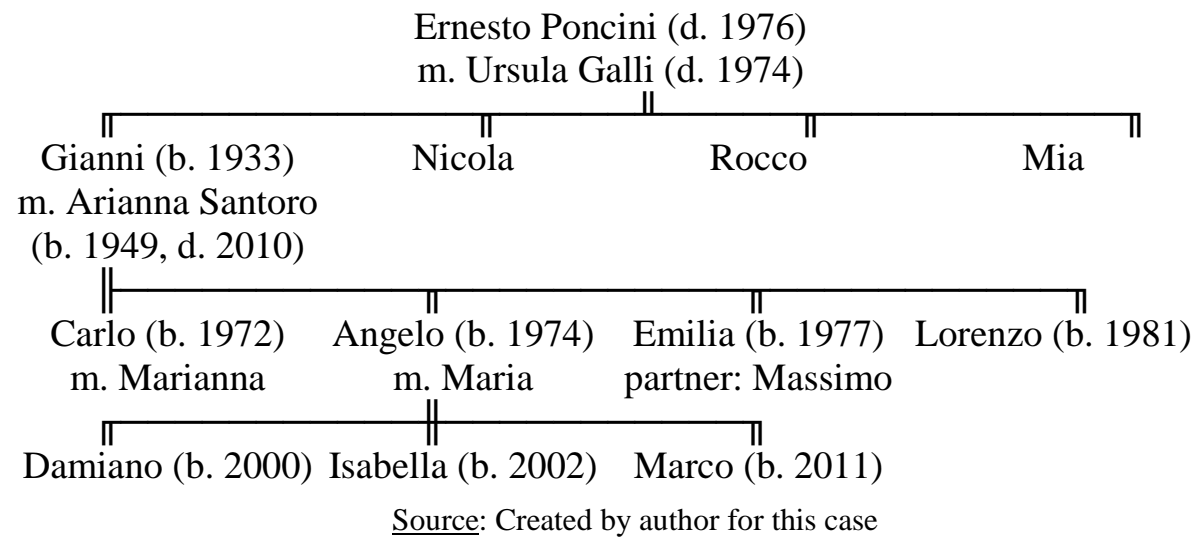

\section{History of the Poncini family's businesses}

Looking back on it, Lorenzo could see that the family business had begun in 1949 when his grandfather, Ernesto, bought the first truck in Cembra. Cembra was a poor village in the valley of the same name, close to Trento. Before that, Ernesto and his wife, Ursula Galli, had had two horse-drawn carts, which Ernesto used to carry wood, potatoes, fruit, wine, and spirits from the valley to the city, and flour, oil, salt, sugar, tobacco, and fertilizer on the return trip to the valley. Ursula not only took care of the house and the children but also looked after the horses at night so they were ready to work at dawn, prepared shipments of goods for the following day, and managed the paperwork.

Ernesto had bought the truck because he could see that things were changing in the transport world, but for some years, the two carts were used alongside the truck. In the mid-1950s with the expansion of transport links outside the area and the development of wood and porphyry 
production, Ernesto disposed of the carts, bought a second truck, and hired his first employee.

In 1957, Ernesto and his family moved to Trento and bought a large property in Dosso Dossi Street, which was big enough to accommodate him and Ursula, as well as all his siblings and their families. The property also had a large space in the back, which he used to store and maintain his trucks. The family began to invest in property, and by 2015 they owned 15 flats. However not all was well. As a consequence of conflicts between Ernesto and his sons, Rocco and Nicola, and to some extent Mia, the truck business, which in 1967 comprised six trucks, was dissolved. In 1968, Gianni, with support from Ernesto and Ursula, opened his own transport company: Gianni Poncini Trasporti. The new company had just one truck. Ursula managed the back office of the new company as well as the original firm.

Arianna, Gianni's wife, proved to be just as dedicated and energetic a contributor to the business as Ursula. Throughout their marriage, she supported Gianni and contributed tirelessly to the management and expansion of the truck company. The family conflicts continued, however, and eventually Gianni and Arianna moved out of their Dosso Dossi Street home. In 1974, Gianni and Arianna bought a piece of land in the countryside, away from the city center and the family conflicts, and built a house and premises for the truck company. They moved there at the end of 1977. In that year, a second company was established: SAPG Autotrasporti, also managed by Arianna (The letters SAPG were the initials of Santoro Arianna Poncini Gianni). The 1970s also saw the construction of a block of 10 flats in the nearby district of Canova; for many years, the rentals from this property financed other family business projects.

In 1981, they purchased more trucks. In 1987, Gianni bought some land suitable for vineyards and planted the first grapes there in 1988. In 2001, Gianni bought more land - two cornfields adjacent to the truck company premises - and converted them into vineyards.

Carlo and Angelo had studied accounting in high school and at the same time helped their parents with the truck company. Carlo was always more interested in transport management and trucks - he started driving them when he was 12. Angelo preferred the management side of the business. Both were employed by the trucking part of the business from 1989 to 1993. Later, Gianni restructured the ownership of the trucking company such that he held 51 percent of the shares with the remainder distributed amongst other members of the immediate family, except for Lorenzo. Lorenzo had never been interested in trucks and preferred not to be involved in the trucking part of the business. Gianni was happy to accommodate this preference as he already had two sons working in the trucking business.

Gianni also established a new company, Immobiliare 2000, of which he was formally the director but, again, Arianna did the day-to-day management. Gianni saw advantages in having Immobiliare 2000 act as a "shell company" to Poncini Autotrasporti, renting premises to it, paying the interest on its debts and generally serving as a barrier against any financial problems it might incur.

In 1996, at the age of 63, Gianni added yet another new activity to the Poncini family businesses; he acquired the retail outlet Porospan 2000, which sold construction tools and materials. The 
family became the exclusive trader of these products for the autonomous provinces of Trento and Bolzano/Bozen. Aerated concrete bricks, under the brand name Porospan, were the most successful product. All family members apart from Lorenzo had shares in this company. This activity, along with grapes and property investments, gave further financial support to the Poncini firm's activities.

In 2000, Gianni and Arianna's younger children, Emilia and Lorenzo, finished high school. Emilia had been born with a physical disability that required many operations while she was growing up. In her early thirties, she often felt severely depressed and only when she was about 35 , when she formed a long-term relationship, did she become happier and more independent. Nevertheless, her link to the family was made stronger by her reliance on the business. As Lorenzo put it, "Mama and all of us - her brothers, I mean - always protected Emilia. To Emilia the family business represented security."

Emilia worked in Poncini Autotrasporti as a secretary between 2001 and 2006, but had helped her mother manage it since 1998. She eventually established and managed its computer systems. Lorenzo, unlike his siblings, did not start working in the family business directly from high school. Rather, he enrolled at the University of Verona to study foreign languages and literature, graduating in 2004. He then enrolled in a Masters program in economics at the University of Trento and did part of his studies for this degree in Ireland and Australia.

In about 2005, Immobiliare 2000 bought two flats, to use as offices, in Dosso Dossi Street from Immobiliare Poncini, the family's original property business, and began repaying the bank loan that financed the purchase. Immobiliare 2000s financial position was precarious, however, because its main customer, Poncini Autotrasporti, did not pay rent on time. Immobiliare 2000 thus "patiently" supported the truck company, even as it started to lose money as a result of a dramatic increase in competition. (At the time of writing the case, the bank account of Immobiliare 2000, the "patient lender" to Poncini Autotrasporti, was overdrawn to the extent of EUR 115,000 from a limit of EUR 120,000.)

In 2010, Gianni decided to change the Poncini farm's name from Gianni Poncini Azienda Agricola to Poncini e Santoro Azienda Agricola, adding Arianna's family name to honor her contribution to the business. He also decided to restructure the ownership of the business. Previously only Angelo and Carlo had been shareholders along with their parents. In the new structure, Gianni and all four children were shareholders. Arianna, who by then had developed a terminal illness, was not a shareholder in order to avoid eventual death duties and legal administrative fees. Everybody was involved in the management of the vineyards especially during the harvest, but from 2010 onwards, Angelo had been formally registered as the farmer.

\section{FAMILY CONFLICTS COME AND GO}

With the new century, one longstanding family conflict ended, although not altogether happily. Ursula had died in 1974, and Ernesto died intestate in 1976. All four of Ernesto's children argued among themselves over the inheritance, especially the property on Dosso Dossi Street. Gianni had bought Mia's shares in the property in the 1970s, but his two brothers continued to argue 
about the property until 2002. Finally, Rocco, ill and in debt, sold his share of the property to Gianni. Gianni, after selling some flats to finance the purchase, owned 57 percent of the Dosso Dossi Street property and formally transferred this asset to his children.

While the dispute between Gianni and his siblings was resolved, some new ones were born. The new disputes included disagreements between Gianni and Vincenzo, one of Gianni’s brothers-inlaw, over the terms of the asset transfer that Vincenzo had made to Arianna. Another dispute erupted after Gianni, Silvio (another of Gianni’s brothers-in-law), and Rosario (Silvio’s son) established a porphyry stone crushing company. This company, instead of providing new activities and synergies for Poncini Autotrasporti, lost money from the very start. Gianni also believed that the new company had snubbed him by not hiring Poncini Autotrasporti to transport the porphyry. Carlo (via Poncini Autotrasporti) had bought shares in the company but sold them at a loss. This hit Poncini Autotrasporti hard because the company was already suffering the effects of the global financial crisis, insolvent customers, and a dispute with an employee. It also led to some ill feelings between Gianni and Carlo. As Lorenzo described it:

Gianni would have liked to have been chairman of the new company. But in the end, Silvio was chosen because he had better connections in the valley. By then, Gianni was no longer closely involved in the trucking business and he simply could not understand how Carlo could lose money on it. He regarded the trucking business as an extension of himself.

Gianni also became dissatisfied with Giulia, one of Arianna's sisters. Giulia, despite being unqualified for the work, had helped out with the accounting for the family's businesses for many years. Gianni’s fault-finding with Giulia led to disputes between Arianna and Giulia, and between Giulia and Maria (Angelo’s wife) who eventually took over Giulia's accounting role. Emilia left the family firm for a temporary job to avoid all the family stress. Gianni's disputes with Arianna's family strained their marriage. Gianni showed his displeasure with his relatives by not asking them to help with the grape harvest, not inviting them to family events, and not speaking to them. Sometimes this treatment was reciprocated.

Around 2005, the family sold a small portion of the vineyards to a large supermarket, which wanted the land to build a new store. The supermarket paid the family EUR 320 per square meter and allowed them to continue to cultivate its part of the vineyards until the sale was finalized. The family was happy with this deal but disagreed about what to do with the money. Angelo and Lorenzo thought they should pay off the bank loan for the Dosso Dossi Street restoration, but Gianni, Arianna, and Carlo decided to finance (for the last time, Arianna said) the truck company. Carlo was affronted by this and pointed out that the truck company had financed the family's other businesses and their holiday house in the mountains. So, it was only fair that when the truck company encountered difficulties, it should receive support.

In 2010, at the age of 60, Arianna died. This had a strong impact on the family and its various businesses. Lorenzo said in 2015, "She [Arianna] was such a calming influence on the whole family. It was so strange that she should die before my father, despite being so much younger. We still feel lost without her." 
Arianna, as mentioned earlier, had managed many of the Poncini family's business activities, and after her death, they were reorganized. A summary of each area of the family business and the involvement of family members in it follows.

\section{TRANSPORT}

Carlo became CEO and the sole owner of Poncini Autotrasporti by buying out all the other shareholders; Gianni was nominated chairman. Carlo then went into two external partnerships. With the first partner in 2012, he opened a second truck company, Ecotrasporti Poncini, whose main activity was the transportation of waste. Carlo and the partner were the shareholders, and the partner helped Carlo get the necessary permits. This further diversification was undertaken because Carlo thought it would be more profitable and have fewer competitors than the original truck business. However, the new company registered a major loss in its first year and the partner left at the beginning of 2013. Carlo merged Ecotrasporti with Poncini Autotrasporti and hired a consultant in business finance and auditing, but this person left after six months. Lorenzo and Angelo agreed to mortgage some flats to help Carlo out, and Gianni took out a loan (with the vineyards as collateral) in favor of Poncini Autotrasporti, but the bank was still reluctant to lend more money to the trucking company.

\section{RETAIL CONSTRUCTION}

Retail construction was no longer part of the main family business because Porospan 2000 closed in 2012 when the brick manufacturing company went bankrupt. Angelo engineered a quiet, rapid closure of Porospan 2000 - even surprising the rest of the family - to avoid an unfavorable tax assessment, and he and Maria later restarted the firm under the name Porospan, with Angelo as CEO. Porospan became profitable again because the American buyer of the original brick manufacturer distributed the bricks through Porospan. Angelo's siblings tacitly resented Angelo and Maria opening Porospan without asking them whether they wished to participate in it. When Lorenzo finally brought up the issue with Angelo in late 2015, Angelo was surprised that the others felt he had been unjust. “After all,” he said, "I paid everybody out.”

\section{PROPERTY}

Lorenzo obtained a qualification in property management and began helping to manage the family's two property businesses, Immobiliare Poncini and Immobiliare 2000, as well as the family's apartments in Canova. Angelo did this task during a time when Lorenzo was

preoccupied with his studies. In 2010 Lorenzo took over full legal and managerial responsibility for these businesses. Lorenzo was not particularly happy about this role and his financial situation in general. As he put it:

When Mama died, I was given her shares in the companies I hadn't had an interest in previously: Porospan 2000 (before Angelo and Maria closed it), Immobiliare 2000, and Poncini Autotrasporti. And Papa later made over a 25 percent share in Poncini e Santoro to each of us (me, Carlo, Angelo and Emilia).

Barrett M. et al. / Wine Business Case Research Journal 1 (1) 2016 


\section{$[\ldots]$}

In addition, I get 5,000 euros for managing the family properties, and that's what I use for day-today expenses. I'm not complaining about what I get. [Managing the properties] is not a big job, and I wouldn't ask more from family members anyway. But it's not a proper income. I'm 33 and still dependent on my dad. I am grateful to have been able to study, but now I also need to think about my future. I can't imagine myself in property management for the rest of my life.

\section{GRAPE GROWING}

Carlo, Angelo, Emilia, and Lorenzo were equal shareholders in the grape growing business with Angelo as its CEO. However, La Vis, the cooperative to which the family had always sent its grapes, had hit financial difficulties, particularly after the GFC. In 2015, La Vis was in its second period of compulsory administration by the provincial authorities of Trentino. According to Lorenzo, La Vis' difficulties were the result of “... over-expansion into too many other businesses such as restaurants elsewhere in Italy. After the GFC La Vis just couldn't service all those mortgages."

Some members of the family including Lorenzo wanted to explore alternatives to La Vis, and others thought maybe the family should get out of the wine business altogether. At the same time, however, expansion was possible; some elderly relatives of the family who had no children were offering to sell the family more land suitable for vineyards.

Exhibit 2 summarizes the development of the Poncini family's various businesses. 


\section{Exhibit 2}

\section{Timeline showing the development of the Poncini family's businesses}

\begin{tabular}{|c|c|}
\hline Year & Event \\
\hline 1949 & $\begin{array}{l}\text { Ernesto Poncini buys the first truck in Cembra, marking the start of the family business. } \\
\text { (see p. 4) }\end{array}$ \\
\hline 1955 & Ernesto sells his carts, buys a second truck. (see p. 4) \\
\hline 1957 & $\begin{array}{l}\text { Ernesto buys a large property in Dosso Dossi Street in Trento to accommodate himself, his } \\
\text { family, his extended family, and to provide space for the trucks. (see p. 4) Begins investing } \\
\text { in property (see p. 4) }\end{array}$ \\
\hline 1967 & $\begin{array}{l}\text { Ernesto's trucking company closes following disputes with his sons Rocco and Nicola. (see } \\
\text { p. 4) }\end{array}$ \\
\hline 1968 & Gianni starts his own transport company (Poncini Autotrasporti). (see p. 4) \\
\hline Early 1970s & Flats constructed in Canova. (see p. 5) \\
\hline 1987 & Gianni buys land for vineyards. (see p. 5) \\
\hline 1988 & First grapes planted. (see p. 5) \\
\hline 1996 & $\begin{array}{l}\text { Beginning of retail construction business (Porospan 2000); its most successful product is } \\
\text { aerated bricks. (see p. 5) }\end{array}$ \\
\hline Early 2000s & $\begin{array}{l}\text { A new property management company, Immobiliare 2000, started. Acts as a "shell } \\
\text { company" to Poncini Autotrasporti. (see p. 5) } \\
\text { Gianni starts a stone crushing company with Vincenzo, one of his brothers-in-law. (see p. } \\
\text { 6) }\end{array}$ \\
\hline 2001 & Gianni buys more land for vineyards. (see p. 5) \\
\hline 2002 & $\begin{array}{l}\text { Immobiliare Poncini, a subsidiary of Immobiliare 2000, is formed to facilitate the transfer } \\
\text { of the Dosso Dossi Street property to Gianni's children. (see p. 5) }\end{array}$ \\
\hline 2005 & A small portion of the vineyards is sold to a supermarket. (p. 7) \\
\hline 2012 & $\begin{array}{l}\text { Porospan } 2000 \text { closes and later reopens as Porospan. (see p. 9) } \\
\text { Poncini Autotrasporti expands into waste transportation via the establishment of } \\
\text { Ecotrasporti Poncini. (see p. 9) }\end{array}$ \\
\hline
\end{tabular}

Source: Poncini Family

\section{GIANNI STEPS DOWN - OR DOES HE?}

As all this was going on, Gianni decided to step down from his role as head of the family firm after a fashion. In early 2015, Gianni was 82. He always had an entrepreneurial spirit and had grown the firm substantially despite the fact that he and Arianna only had five years of primary education. Gianni had had a heart operation a few years ago and had been hospitalized briefly for other problems in May 2015. He had always recovered well and resumed going to work every day, even insisting on driving the forklift. But, in Lorenzo's opinion, he was becoming less able to manage the various family enterprises. In 2011, Gianni passed all his properties and company 
shares to his children, retaining the right to use one-fifth of one of the properties in Canova, and right of residence in one flat in the Dosso Dossi Street property.

\section{Lorenzo said:}

It's obvious that Papa should slow down, but he just won't admit it. Still, it's just as obvious that we can't keep relying on Papa to make all the decisions. But that still leaves the basic problem: how should we make decisions in future? 